\title{
STUDY ON ISOLATION, IDENTIFICATION AND LEAD BIOSORPTION CAPABILITY OF A LEAD-TOLERANT PENICILLIUM SP. Pb-G FROM CONTAMINATED SOIL
}

\author{
AN, F. Q. ${ }^{1 *}-$ LI, H. H. ${ }^{1}-$ ZHAO, Q. Q. ${ }^{1}-$ LI, B. H. ${ }^{1}-$ LV, J. L. ${ }^{2}$ \\ ${ }^{I}$ College of Environmental and Chemical Engineering, Xi'anPolytechnic University, Xi'an, \\ Shaanxi 710048, China \\ ${ }^{2}$ College of Natural Resources and Environment, Northwest A\&F University, Ministry of \\ Agriculture Key Laboratory of Plant Nutrition and Agri-environment in Northwest China, \\ Yangling, Shaanxi 712100, China \\ ${ }^{*}$ Corresponding author \\ e-mail:20130503@xpu.edu.cn; phone:+86-181-9235-9615
}

(Received $12^{\text {th }}$ Feb 2020; accepted $9^{\text {th }}$ Jul 2020)

\begin{abstract}
To acquire a potential strain that may be used for the bioremediation of lead $\left(\mathrm{Pb}^{2+}\right)$ contaminations, an indigenous lead-resistant fungus Penicillium sp. Pb-G (GenBank No.MK372218) was isolated from lead contaminated soil, and the $\mathrm{Pb}^{2+}$ biosorption characteristics were determined in this study. The results showed that Penicillium sp. $\mathrm{Pb}-\mathrm{G}$ was highly tolerant to $\mathrm{Pb}^{2+}$, and it could survive on PDA medium with $\mathrm{Pb}^{2+}$ concentration up to $4000 \mathrm{mg} / \mathrm{L}$. Under these circumstances, the spores of the strain $\mathrm{Pb}-\mathrm{G}$ becomes shrunk and malformed as observed by scanning electron microscopy (SEM). X-ray diffractometer (XRD) analysis further revealed that the Penicillium sp. Pb-G's mycelia had a good biosorption capability for $\mathrm{Pb}^{2+}$. The best biosorption effect of strain Penicillium sp. $\mathrm{Pb}-\mathrm{G}$ was recorded at the $\mathrm{Pb}^{2+}$ concentration of $1500 \mathrm{mg} / \mathrm{L}$, with the biosorption rate and biosorption amount of $53.05 \%$ and $178.02 \mathrm{mg} / \mathrm{g}$, respectively. Collectively, these results demonstrated that the strain of $\mathrm{Pb}-\mathrm{G}$ had strong $\mathrm{Pb}^{2+}$ resistance and biosorption abilities, which provides an attractive application prospect in bioremediation of heavy metal contamination.
\end{abstract}

Keywords:maximum resistance level, identification, Penicillium, scanning electron microscopy, X-ray diffractometer

\section{Introduction}

Heavy metal pollution in soil and water has become an increasingly prominent environmental problem, among the heavy metals lead gained special attention as a pollutant due to its high persistence and toxicity. It mainly derives from minerals, metal smelting, leaded gasoline, municipal sewage, industrial waste and paint spraying (Gisbert et al., 2003; Ganesh et al., 2015). It could be taken up by various crops and then threaten human health (Szczygłowska et al., 2011; An et al., 2018). Conventional physical and chemical approaches applied for the remediation of heavy metal have several drawbacks, such as high operational cost, low removal rate and secondary pollution. Microbes are widely present in the soil, due to their large surface area, they have strong adsorption capability for heavy metals and without any undesirable effects, thus, using microorganisms as an alternative biomaterial in dealing with heavy metal contaminated wastewater and soil have been widely concerned by scientists and become the research hot spots in the field of green environmental protection (Velmurugan et al., 2010; Wu et al., 2010;Deng et al., 2011;Kayalvizhi et al., 2019).

Generally, contaminated soils are sources of heavy metal tolerant microorganisms. Recent studies indicated that there existed a certain amount of anti-heavy metal 
microbial groups in soils that have been subjected to one or more heavy metal stresses for a long time, including bacteria, fungi, actinomycetes and algae, and these microbial groups usually have strong biosorption capacity for heavy metals (Wu et al., 2010; Jacob et al., 2013; Iram et al., 2015; Kayalvizhi et al., 2019). Fungi have been recognized as one promising class of low-cost biosorbents for the removal of heavy metal ions from aqueous waste streams. There are several mechanisms in fungi to tolerate and detoxify metals, including extra and intracellular precipitation, transformation of metals, and biosorption to cell wall. The cell walls of fungi are composed of polysaccharides, proteins, and lipids that contain reactive functional ingredients with potential metal binding capacities (Viraraghavan et al., 2011; Mohammadian et al., 2017).

Terry et al. (2018) reported that a total of 425 fungal strains were obtained from tropical forest soil, which showed heavy metal tolerance, the most common and diverse genera isolated were identified as Penicillium. Since the fungus Penicillium has strong vitality, rapid reproduction and extensive sources in environments, and it had been found as being most tolerant to many kinds of heavy metals, such as $\mathrm{Zn}, \mathrm{Hg}, \mathrm{Cr}$ and $\mathrm{Pb}$ (Ye et al., 2018; Kayalvizhi et al., 2019; Chang et al., 2020; Long et al., 2020), its antilead characteristics have been studied by some researchers particularly (Zucconi et al., 2003; Say et al., 2003; Velmurugan et al., 2010; Mohammadian et al., 2017; Ye et al., 2018). Zucconi et al. (2003) reported that a strain of Penicillium (Penicillium lilacinus) can grow in a medium containing $\mathrm{Pb}^{2+}$ up to $1434 \mathrm{mg} / \mathrm{L}$. As reported by Sun et al. (2007), Penicillium sp. Psf-2 can grow in a solution with $\mathrm{Pb}^{2+}$ concentration of 4 $\mathrm{mmol} / \mathrm{L}$. Velmurugan et al. (2010) isolated a high lead-resistant strain (Penicillium sp. MRF-1) from South Korean mining soil, where the lead content is $357 \mathrm{mg} / \mathrm{kg}$, the strain showed high removal efficiency of $\mathrm{Pb}^{2+}$, so it would be an excellent biosorbent for the removal of lead from aqueous solution. The Penicillium oxalicum SL2 had tolerance to $1000 \mathrm{mg} / \mathrm{L} \mathrm{Cr}^{6+}$ and $2500 \mathrm{mg} / \mathrm{L} \mathrm{Pb}^{2+}$ in potato-dextrose agar, and had excellent removal efficiency of $\mathrm{Cr}^{6+}$ and $\mathrm{Pb}^{2+}$ via reduction with acidic metabolites and form transformation in the mycelium, the strain showed a promising new candidate for bioremediation of heavy metal pollution (Ye et al., 2018; Long et al., 2020).

Most previous reports on heavy metal resistant fungi have been focusing on the adsorption capacity of dead fungi biomass, and less on the biosorption capacity of living fungi biomass (Say et al., 2003; Fan et al., 2008; Velmurugan et al., 2010). Moreover, although these studies showed that Penicillium was tolerant to $\mathrm{Pb}^{2+}$ and had $\mathrm{Pb}^{2+}$ biosorption capability, their performance about tolerance and biosorption were slightly weak. Therefore, it is far-reaching significant to use living fungi to cope with the seriously lead contaminated soil for long-term bioremediation effect.

In this study, a fungus strain with high Pb-resistance was isolated and acclimated from $\mathrm{Pb}$-contaminated soil, and its biological characteristics were studied. The biosorption effects of $\mathrm{Pb}^{2+}$ by living strains were also determined. This study would potentially provide a theoretical basis for the bioremediation of lead pollution in the environment.

\section{Materials and methods}

\section{Collection of soil samples and Pb content analysis of soil samples}

The soil samples were collected from a demonstration zone of the National Loess Fertility and Fertilizer Benefit Monitoring Base in Wuquan Town, Yangling County, 
Shaanxi Province $\left(34^{\circ} 17^{\prime} 51^{\prime \prime} \mathrm{N}, 108^{\circ} 00^{\prime} 48^{\prime \prime} \mathrm{E}\right)$, China. In the test site, $350 \mathrm{mg} / \mathrm{kg} \mathrm{Pb}$ (in the form of $\mathrm{Pb}\left(\mathrm{NO}_{3}\right)_{2}$ solution) was artificially added in the soil in May 2010. The surface soil $(0-20 \mathrm{~cm})$ was collected with the Z-shape 5-point sampling method in December 2013. After mixed, approximately $0.5 \mathrm{~kg}$ of soil from each site was collected. A standard soil corer device was used to collect samples without disturbing plant roots. Five collected soil cores from each plot were pooled as a replicate. A total of 3 sample replicates were transferred to laboratory. The soil samples were sieved through 2-mm mesh to remove plant residues and stones. A subsample of each soil core was sealed in a sterilized self-sealing bag in an icebox and delivered to laboratory, then stored in the refrigerator at $4^{\circ} \mathrm{C}$ for isolating fungal strains. The remaining sample was air-dried at room temperature until a stable weight was reached, and air-dried soil samples were ground and passed through a $0.25-\mathrm{mm}$ sieve for $\mathrm{Pb}$ content analysis.

Total concentration of $\mathrm{Pb}$ in the soils were determined by standard soil testing procedures (Bao, 2000), $5 \mathrm{~g}$ soil samples were digested by $\mathrm{HNO}_{3}: \mathrm{HCl}: \mathrm{HClO}_{4}(1: 2: 2)$ to extract the total $\mathrm{Pb}$. Total $\mathrm{Pb}$ concentration was measured with ICP-MS (Thermo, model Xseries II, USA).

\section{Isolation of Pb-tolerant fungal strain}

A total of $10 \mathrm{~g}$ of the collected soil sample was weighed and dissolved in $100 \mathrm{~mL}$ distilled water held in a $500-\mathrm{mL}$ flask. The mixture was shaken at $25{ }^{\circ} \mathrm{C}, 120 \mathrm{r} / \mathrm{min}$ for $2 \mathrm{~h}$ and kept still for $20 \mathrm{~min}, 1 \mathrm{~mL}$ of the suspension was removed and diluted to $10^{-1}$, $10^{-2}, 10^{-3}$, and $10^{-4}$ concentrations with a gradient-dilution method ( $\mathrm{Li}$ et al., 2010b). With a sterilized pipettor, $100 \mu \mathrm{L}$ of each dilution was transferred onto potato-dextrose agar (PDA) plates supplemented with 200, 300, 400 and $500 \mathrm{mg} / \mathrm{L}$ of $\mathrm{Pb}^{2+}$, respectively. The plates were incubated at $28^{\circ} \mathrm{C}$ for $5-7 \mathrm{~d}$, three replications were performed for each treatment. According to fungus growing characteristics, the blooming colonies with different morphology were picked and re-inoculated onto new PDA plates until the pure strain was obtained. The obtained strains were further examined on PDA plates that contain 600,800 and $1000 \mathrm{mg} / \mathrm{L}$ of $\mathrm{Pb}^{2+}$, respectively. After isolation, the obtained pure strains were preserved with PDA slant and glycerol media. All the operations were conducted under sterilized conditions.

The above PDA culture medium formula was: peeled potato $200.0 \mathrm{~g}$, glucose $15.0 \mathrm{~g}$, peptone $3.0 \mathrm{~g}, \mathrm{MgSO}_{4} 2.0 \mathrm{~g}, \mathrm{KH}_{2} \mathrm{PO}_{4} 3.0 \mathrm{~g}$, agar powder $15.0 \mathrm{~g}$, and distilled water $1000 \mathrm{~mL} . \mathrm{Pb}\left(\mathrm{NO}_{3}\right)_{2}$ solution was prepared and stored at $4{ }^{\circ} \mathrm{C}$ for adding to the PDA medium.

\section{Maximum $P b$ resistance level of strain $P b-G$}

The maximum concentration of the heavy metal that a strain can tolerated is the maximum resistance level (MRL). To determine the MRL of the isolated strain, the strain was cultivated with PDA containing different concentrations of sterilized $\mathrm{Pb}\left(\mathrm{NO}_{3}\right)_{2}$ solution. Five $\mathrm{Pb}^{2+}$ concentrations (treatments) were selected, that is, $0 \mathrm{mg} / \mathrm{L}$ (CK), $1000 \mathrm{mg} / \mathrm{L}, 2000 \mathrm{mg} / \mathrm{L}, 3000 \mathrm{mg} / \mathrm{L}$ and $4000 \mathrm{mg} / \mathrm{L}$, three replicates per treatment. After 5 days of cultivation at $28^{\circ} \mathrm{C}$, the colonies were observed and photographed.

\section{Molecular identification for strain Pb-G}

The conservative ITS rRNA gene in fungi was used to identify the screened $\mathrm{Pb}-\mathrm{G}$ strain. The ITS rRNA gene form $\mathrm{Pb}-\mathrm{G}$ was amplified using the primer ITS1 (5'- 
TCCGTAGGTGAACCTGCGG-3') and ITS4 5'-TCCTCCGCTTATTGATATGC-3') (Velmurugan et al., 2010). The PCR amplification system was $50 \mu \mathrm{L}$, containing $5 \mu \mathrm{L}$ $10 \times$ LA Taq Buffer II $\left(\mathrm{Mg}^{2+}\right.$ Plus (TaKaRa, Japan), $8 \mu \mathrm{L}$ dNTP, 5 U LA Taq enzyme (TaKaRa), $1 \mu \mathrm{L}$ of each primer $(0.5 \mathrm{mmol} / \mathrm{L})$, and $2 \mu \mathrm{L} 10.3 \mathrm{ng} / \mu \mathrm{L}$ DNA template). The PCR program was as follows: pre-denaturation at $94^{\circ} \mathrm{C}$ for $5 \mathrm{~min}, 31$ cycles of denaturation at $94^{\circ} \mathrm{C}$ for $45 \mathrm{~s}$, annealing at $58^{\circ} \mathrm{C}$ for $45 \mathrm{~s}$, extension at $72^{\circ} \mathrm{C}$ for $90 \mathrm{~s}$, and finally preservation at $4^{\circ} \mathrm{C}$ for less than $12 \mathrm{~h}$. The PCR products were detected by agarose gel electrophoresis, and the qualified ones were sent to the Beijing Liuhe Huada Gene Technology Co., Ltd. for sequencing the ITS gene.

To analyze the homology of the strain, the sequences of the samples were aligned against NCBI databases (http://www.ncbi.nih.gov/index.html) by BLAST, and a phylogenetic tree was constructed using the software MEGA 5.05, using Neighbor-joining analysis for the ITS rRNA.

\section{Effects of temperature and $\mathrm{pH}$ on the growth of $\mathrm{Pb}-\mathrm{G}$}

Temperature and $\mathrm{pH}$ are the decisive factors affecting the growth of the strain, and the metabolic rate and growth rate of the strain will be increased at the appropriate temperature and $\mathrm{pH}$. Therefore, the two factors were selected to determine the optimal growth conditions of the strain.

The Penicillium sp. Pb-G strain was rejuvenated on PDA medium without $\mathrm{Pb}^{2+}$, and then agar dishes attached with plenty of mycelia were taken out using a sterilized hole puncher $(\Phi=1.2 \mathrm{~cm})$. The agar dishes were put onto PDA medium and inoculated for 7 d at $20{ }^{\circ} \mathrm{C}, 25^{\circ} \mathrm{C}, 30^{\circ} \mathrm{C}$ and $35^{\circ} \mathrm{C}$, respectively. The colony diameter was then measured by the Cross-crossing method at a fixed time every day. The colonial average growth rate was calculated according to equation (1):

$$
G_{t}=\frac{D_{t}-D_{0}}{t}
$$

where, $G_{t}(v, \mathrm{~cm} / \mathrm{d})$ is the average growth rate; $D_{t}(\varphi, \mathrm{cm})$ is the average colony diameter; $D_{o}(\varphi, \mathrm{cm})$ is the disk diameter, and $t(\mathrm{~d})$ is the culture time.

The $\mathrm{pH}$ of solid PDA medium was adjusted to 6.0, 7.0, 8.0 and 9.0 respectively using sterilized $1 \mathrm{~mol} / \mathrm{L} \mathrm{HCl}$ and $\mathrm{NaOH}$ solutions. The rejuvenated Penicillium sp. $\mathrm{Pb}-\mathrm{G}$ were then inoculated onto these media by agar dish inoculation method using a sterilized hole puncher $(\Phi=1.2 \mathrm{~cm})$ and cultivated at $25^{\circ} \mathrm{C}$ for $7 \mathrm{~d}$. Every treatment repeats three times. The colonial diameter was measured by the Cross-crossing method at a fixed time every day. The colonial average growth rate was also calculated according to equation (Eq.l).

\section{Scanning electron microscopy (SEM) analysis}

The scanning electron microscopy (SEM) was used to analyze the morphological characteristics of Penicillium sp. $\mathrm{Pb}-\mathrm{G}$ cultured in different $\mathrm{Pb}^{2+}$ concentrations. The sterilized $\mathrm{Pb}\left(\mathrm{NO}_{3}\right)_{2}$ solution was added into PDA medium to get the final concentrations of $0 \mathrm{mg} / \mathrm{kg}$ (CK), $2000 \mathrm{mg} / \mathrm{kg}, 3000 \mathrm{mg} / \mathrm{kg}$ and $4000 \mathrm{mg} / \mathrm{kg}$. The Penicillium sp. Pb-G was then inoculated in these PDA liquid media at $28^{\circ} \mathrm{C}$. After $5 \mathrm{~d}$, fungal biomass was harvested by centrifugation at $8000 \mathrm{r} / \mathrm{min}\left(15^{\circ} \mathrm{C}\right)$ for $10 \mathrm{~min}$. To remove any loosely associated and unsequestered $\mathrm{Pb}^{2+}$, the collected mycelia were soaked in $2 \%$ oxalic acid for $10 \mathrm{~min}$ and then soaked in distilled water for another $10 \mathrm{~min}$ for two times. Then the samples were dried by vacuum freeze drier (Thermo Fisher, USA), coated with gold and 
examined under SEM (FLEXSEM1000, Hitachi, Japan), photographed with optimum magnification (Glukhova et al., 2018).

\section{$X$-ray diffraction (XRD) analysis}

To analyze the $\mathrm{Pb}^{2+}$ biosorption capability of Penicillium sp. $\mathrm{Pb}-\mathrm{G}$, it was cultivated in PDA liquid medium with $\mathrm{Pb}\left(\mathrm{NO}_{3}\right)_{2}$ concentrations of $0 \mathrm{mg} / \mathrm{L}(\mathrm{CK})$ and $4000 \mathrm{mg} / \mathrm{L}$ respectively. Every concentration was set for three repetitions. The strain was cultured on an oscillator at $25^{\circ} \mathrm{C}, 120 \mathrm{r} / \mathrm{min}$ for $5 \mathrm{~d}$, centrifuged at $6000 \mathrm{r} / \mathrm{min}$ for $15 \mathrm{~min}$ to precipitate the fungal biomass, the supernatant was discarded and the precipitates were rinsed with distilled water, repeat these steps twice. The precipitates were taken out and dried at $65^{\circ} \mathrm{C}$. After grinding the sample was analyzed by an XRD (Nippon science Minniflex 600, Japan), and parameters were set as the light pipe current, $15 \mathrm{~mA}$; the voltage, $40 \mathrm{kV}$; the width of the slit, $0.02 \mathrm{deg}$; the scanning angular velocity, $0.25 \% \mathrm{~min}$; and the scanning angle ranging from $3^{\circ}$ to $90^{\circ}$. The characteristics of Penicillium sp. PbG were analyzed and plotted by MDI Jade 6.5 software (Materials Data Inc. Liverpool, $\mathrm{CA}$ ) and Origin 8.5 (Origin Lab, USA) respectively based on the average value of three repetitions.

\section{Biosorption properties of the strain $\mathrm{Pb}-\mathrm{G}$ to $\mathrm{Pb}^{2+}$}

The mycelium from the vigorous Penicillium sp. $\mathrm{Pb}-\mathrm{G}$ colony was picked, inoculated into $100 \mathrm{~mL}$ PDA liquid medium, and cultivated on a shaker at $120 \mathrm{r} / \mathrm{min}$ and $25^{\circ} \mathrm{C}$. After $5 \mathrm{~d}$ of inoculation, the fungus was filtered with four layers of gauze, rinsed three times with deionized water, dried together with filter paper, and then weighted.

To examine the biosorption capability of $\mathrm{Pb}-\mathrm{G}$, the collected mycelium was inoculated in $\mathrm{Pb}\left(\mathrm{NO}_{3}\right)_{2}$ solution $(\mathrm{pH}=7)$ with initial $\mathrm{Pb}^{2+}$ concentrations of $0 \mathrm{mg} / \mathrm{L}(\mathrm{CK})$, $500 \mathrm{mg} / \mathrm{L}, 1000 \mathrm{mg} / \mathrm{L}, 1500 \mathrm{mg} / \mathrm{L}, 2000 \mathrm{mg} / \mathrm{L}$ and $2500 \mathrm{mg} / \mathrm{L}$ respectively, three repeats per $\mathrm{Pb}^{2+}$ concentration. For inoculation, $1 \mathrm{~g}$ fungi were put into $50 \mathrm{~mL} \mathrm{~Pb}\left(\mathrm{NO}_{3}\right)_{2}$ solution contained in a flask, fully dispersed by a glass rod, and shaken on shaker at $25^{\circ} \mathrm{C}, 150 \mathrm{r} / \mathrm{min}$. After $24 \mathrm{~h}$, all the mycelia were filtered with the filter paper, and then the hyphae were dried to a constant weight in a drying oven at $80{ }^{\circ} \mathrm{C}$ for $12 \mathrm{~h}$ with the filter paper together. The weight of the filter paper was then subtracted to obtain the dry weight of the biomass. Finally, the collected mycelia weight was calculated (Pan et al., 2010). The biosorption rate $(Q)$ and the biosorption amount $(q, \mathrm{mg} / \mathrm{g})$ of fungus Penicillium sp. $\mathrm{Pb}-\mathrm{G}$ were calculated based on mycelium dry weight according to the equation (Eq.2) and (Eq.3), respectively.

$$
\begin{gathered}
Q=\frac{\left(C_{0}-C_{t}\right)}{C_{0}} \times 100 \% \\
q=\frac{\left(C_{0}-C_{t}\right)}{m} \times V
\end{gathered}
$$

where, $C_{0}(\mathrm{mg} / \mathrm{L})$ is the initial $\mathrm{Pb}^{2+}$ concentration before biosorption; $C_{\mathrm{t}}(\mathrm{mg} / \mathrm{L})$ is the final $\mathrm{Pb}^{2+}$ concentration after biosorption; $V(\mathrm{~L})$ is the volume of the reaction solution; and $m(\mathrm{~g})$ is the mass of dried biomass of fungi in the reaction solution.

The supernatant was digested by nitric acid $\left(\mathrm{HNO}_{3}\right)$ and hydrogen peroxide $\left(\mathrm{H}_{2} \mathrm{O}_{2}\right)$ for measuring $\mathrm{Pb}^{2+}$ amount. 


\section{Data analysis}

The growth rate and biosorption capability were performed with three repetitions and the data were reported as mean \pm standard deviation (SD) in the figures and table. The significant differences among the treatments were evaluated using One-way analysis of variance (ANOVA) followed by LSD test at a level of $p<0.05$ using SPSS 22.0 software for Windows (SPSS Inc., Chicago, IL, USA).

\section{Results}

\section{The maximum resistance level of strain $\mathrm{Pb}-\mathrm{G}$}

The average concentration of total $\mathrm{Pb}$ in collected soil samples was $331.13 \mathrm{mg} / \mathrm{kg}$ that exerted a selection pressure on microbial communities, including filamentous fungi. After isolation and culturing, a strain of fungus with high resistance capacity to $\mathrm{Pb}^{2+}$ was obtained, named $\mathrm{Pb}-\mathrm{G}$. The center of the colony was cyan, and the periphery of the colony showed white. The Figurel demonstrated that the morphology of the Penicillium $\mathrm{sp}$. $\mathrm{Pb}-\mathrm{G}$ remained same with the blue-green color and no prominent changes were detected under the different concentration of $\mathrm{Pb}^{2+}$ from 1000 to $2000 \mathrm{mg} / \mathrm{L}$. Whereas, when the $\mathrm{Pb}^{2+}$ concentration was raised to $3000 \mathrm{mg} / \mathrm{L}$, the growth of strain $\mathrm{Pb}-\mathrm{G}$ slowed down, showing low hyphae amount, deeper color and white colony edge, which indicated that the growth of the fungi was inhibited to a certain extent and when $\mathrm{Pb}^{2+}$ reached up to $4000 \mathrm{mg} / \mathrm{L}$ in the medium, $\mathrm{Pb}-\mathrm{G}$ strain still grew, but the number of hyphae was reduced, the colony was obviously small in diameter, and no obvious changes were found for hyphae even after $25 \mathrm{~d}$ of cultivation. So the MRL of the Pb-G strain was $4000 \mathrm{mg} / \mathrm{L}$.

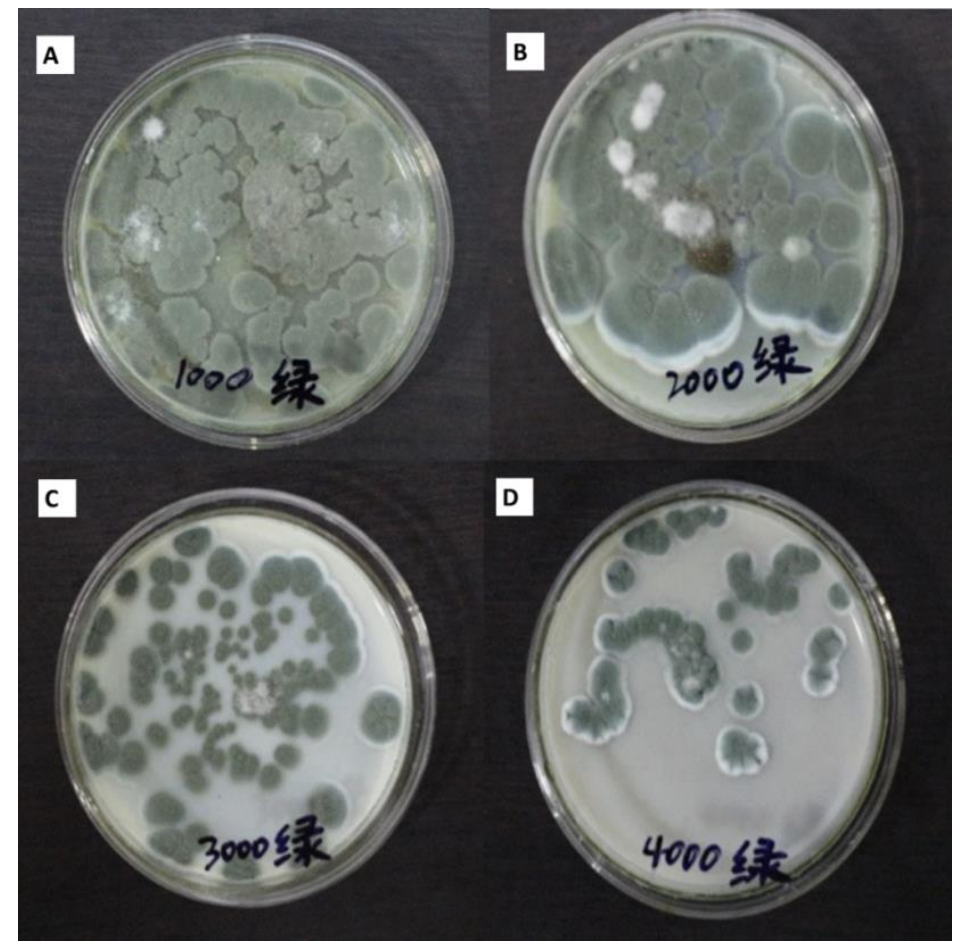

Figure 1. The growth status of Penicillium sp. $P b-G$ in medium with different concentrations of $\mathrm{Pb}^{2+}$. A, $1000 \mathrm{mg} / \mathrm{L} ; \mathrm{B}, 2000 \mathrm{mg} / \mathrm{L} ; \mathrm{C}, 3000 \mathrm{mg} / \mathrm{L} ; \mathrm{D}, 4000 \mathrm{mg} / \mathrm{L}$ 


\section{Molecular identification of the Pb-tolerant microorganism (Pb-G)}

The ITS rRNA gene was amplified from $\mathrm{Pb}-\mathrm{G}$ stain and analyzed by software MEGA 5.05. The ITS rRNA gene in Pb-G strain was about $600 \mathrm{bp}$ in length, the ITS rRNA sequence of $\mathrm{Pb}-\mathrm{G}$ was deposited to GenBank and accession number was obtained, the GenBank accession was No. MK372218 (http://www.ncbi.nih.gov/index.html). A phylogenetic tree was constructed with the obtained homologous sequences from GenBank according to the sequence similarity over 97\% using the ITS nuclear ribosomal RNA (Torres et al., 2018). If the similarity of ITS rRNA gene sequences was more than $99 \%$ between a studied strain and its nearest neighbor, the strain can be identified as the same species with its nearest neighbor (Mohammadian et al., 2017). In the present study the results of phylogenetic tree showed the strain $\mathrm{Pb}-\mathrm{G}$ was closely related to Penicillium in evolution, and its nearest neighbor was the Penicillium JN397373.1 in the phylogenetic tree (Figure2). Therefore, based on the fungal morphology and sequence alignment of ITS rRNA gene, the strain $\mathrm{Pb}-\mathrm{G}$ was identified as Penicillium genus.

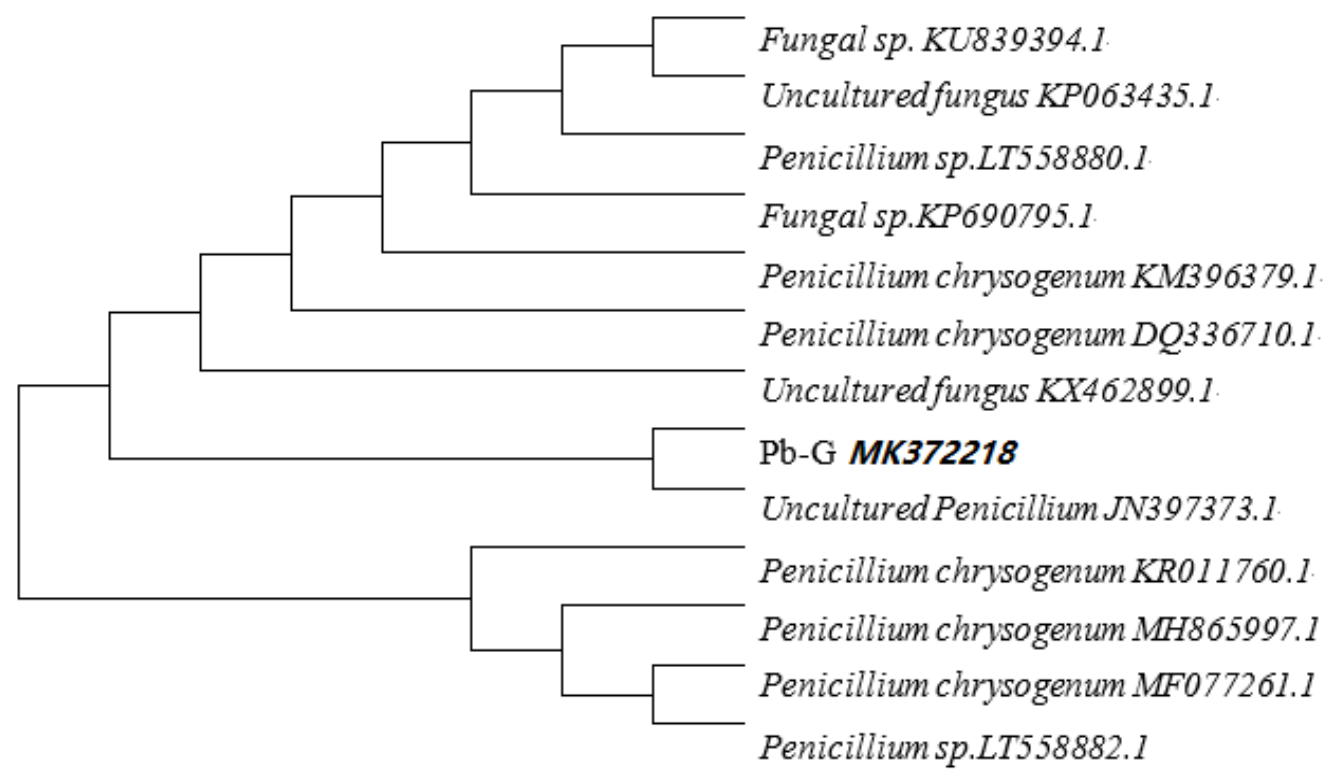

Figure 2. The phylogenetictree of strainstolerantto $\mathrm{Pb}^{2+}$

\section{Effects of different temperatures and $\mathrm{pH}$ on the growth of $\mathrm{Pb}-\mathrm{G}$}

The growth rate of Penicillium sp. $\mathrm{Pb}-\mathrm{G}$ changed under the influence of different temperatures (Figure3). On the first day, the Penicillium sp. Pb-G strain at $25{ }^{\circ} \mathrm{C}$ grew slowly, the strain at other temperatures did not change at all. On the 2-4th day, Penicillium sp. $\mathrm{Pb}-\mathrm{G}$ had the highest growth rate at $25^{\circ} \mathrm{C}$, while they grew fast at $20{ }^{\circ} \mathrm{C}$ on the 4-7th day. For the Penicillium sp. $\mathrm{Pb}-\mathrm{G}$ at $30^{\circ} \mathrm{C}$, they grew fast on the 2-4th day, but the growth rate decreased on the 4-7th day. The Penicillium sp. Pb-G was almost no obvious growth at $35^{\circ} \mathrm{C}$. These results indicated that the strain $\mathrm{Pb}-\mathrm{G}$ grow well within the temperature range of $20-30{ }^{\circ} \mathrm{C}$, but inhibited at $35^{\circ} \mathrm{C}$, therefore, $25^{\circ} \mathrm{C}$ was the most suitable temperature for its growth. 


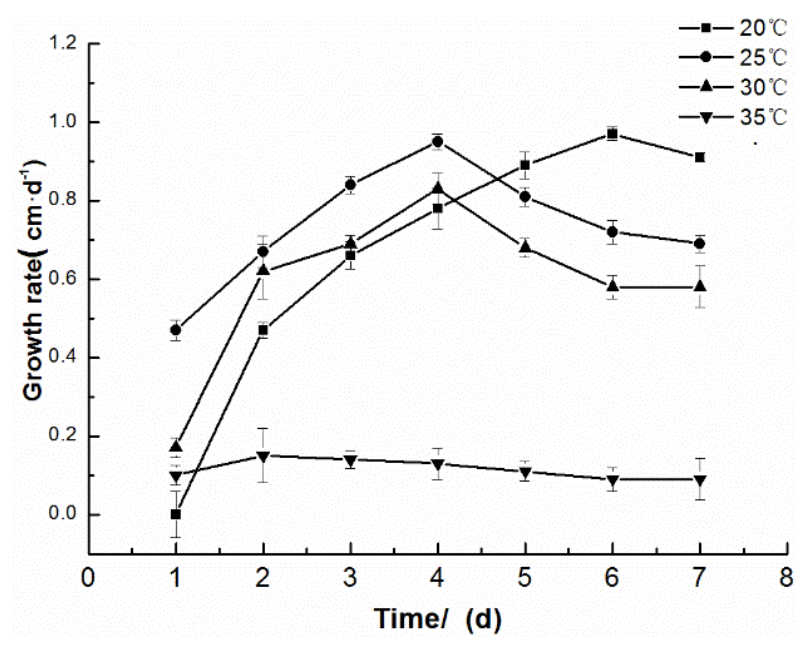

Figure 3. Effects of different temperatures on the growth rate of Penicillium sp. $\mathrm{Pb}-\mathrm{G}$.

Data are means $\pm S D(n=3)$

The growth rate of strain Penicillium sp. $\mathrm{Pb}-\mathrm{G}$ also changed under the influence of different $\mathrm{pH}$ values (Figure4). The growth rate of Penicillium sp. $\mathrm{Pb}-\mathrm{G}$ was highest at $\mathrm{pH} 7$ among all $\mathrm{pH}$ conditions, followed by the growth rate at $\mathrm{pH} 6$, while it was decreased when the $\mathrm{pH}$ reached up to 8 and 9. The results indicated that the $\mathrm{pH} 7$ was the optimal $\mathrm{pH}$ value for the strain growth, and the growth rate reached the highest on the 4th day.

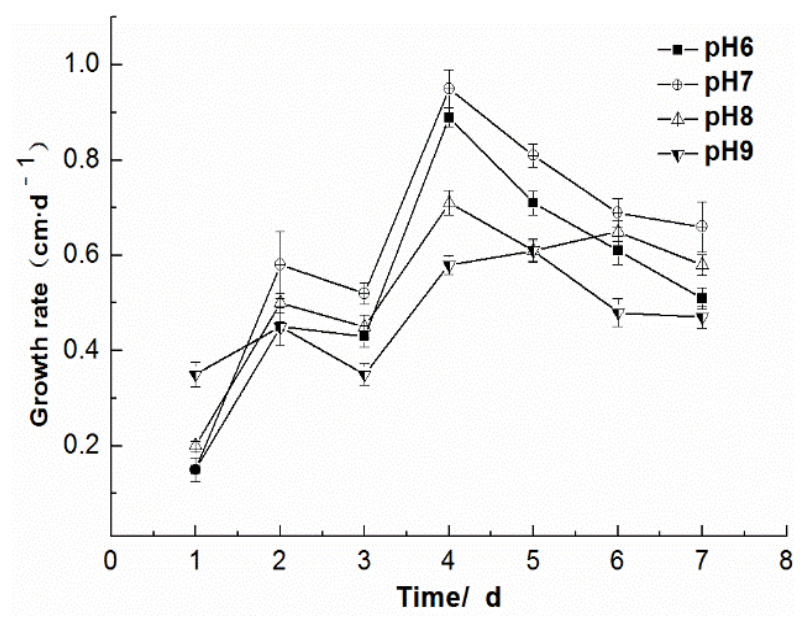

Figure 4. Effects of different $p H s$ on the growth rate of Penicillium sp.Pb-G.

Data are means $\pm S D(n=3)$

\section{Morphological characteristics of strain Pb-G's spores with different $\boldsymbol{P b}^{2+}$ concentrations}

The spore morphologies of the Penicillium sp. $\mathrm{Pb}-\mathrm{G}$ in medium with different $\mathrm{Pb}^{2+}$ concentrations were observed by scanning electron microscopy. As shown in Figure 5, the spores of Penicillium sp. $\mathrm{Pb}-\mathrm{G}$ in the $\mathrm{CK}$ group $\left(0 \mathrm{mg} / \mathrm{kg}\right.$ of $\left.\mathrm{Pb}^{2+}\right)$ were more than that treated under $4000 \mathrm{mg} / \mathrm{kg}$ of $\mathrm{Pb}^{2+}$, and the individuals were full and evenly 
distributed. However, the amount of spores was reduced under different $\mathrm{Pb}^{2+}$ treatments, and it showed morphologies of collapse, shrinkage and deformity. Furthermore, some spores dissolved and joined into pieces in "strips" shape (as indicated by the arrows). With the increase of $\mathrm{Pb}^{2+}$ concentration, the phenomenon of spore shrinkage and connection into pieces also increased. After magnified, the Penicillium $\mathrm{sp}$. $\mathrm{Pb}-\mathrm{G}$ spores under the $4000 \mathrm{mg} / \mathrm{kg}$ of $\mathrm{Pb}^{2+}$ treatment showed obvious distortion and deformation compared with the CK group, and some of them had irregularly shaped blocky material attached, as shown by the arrows (Figure 5-E and F).

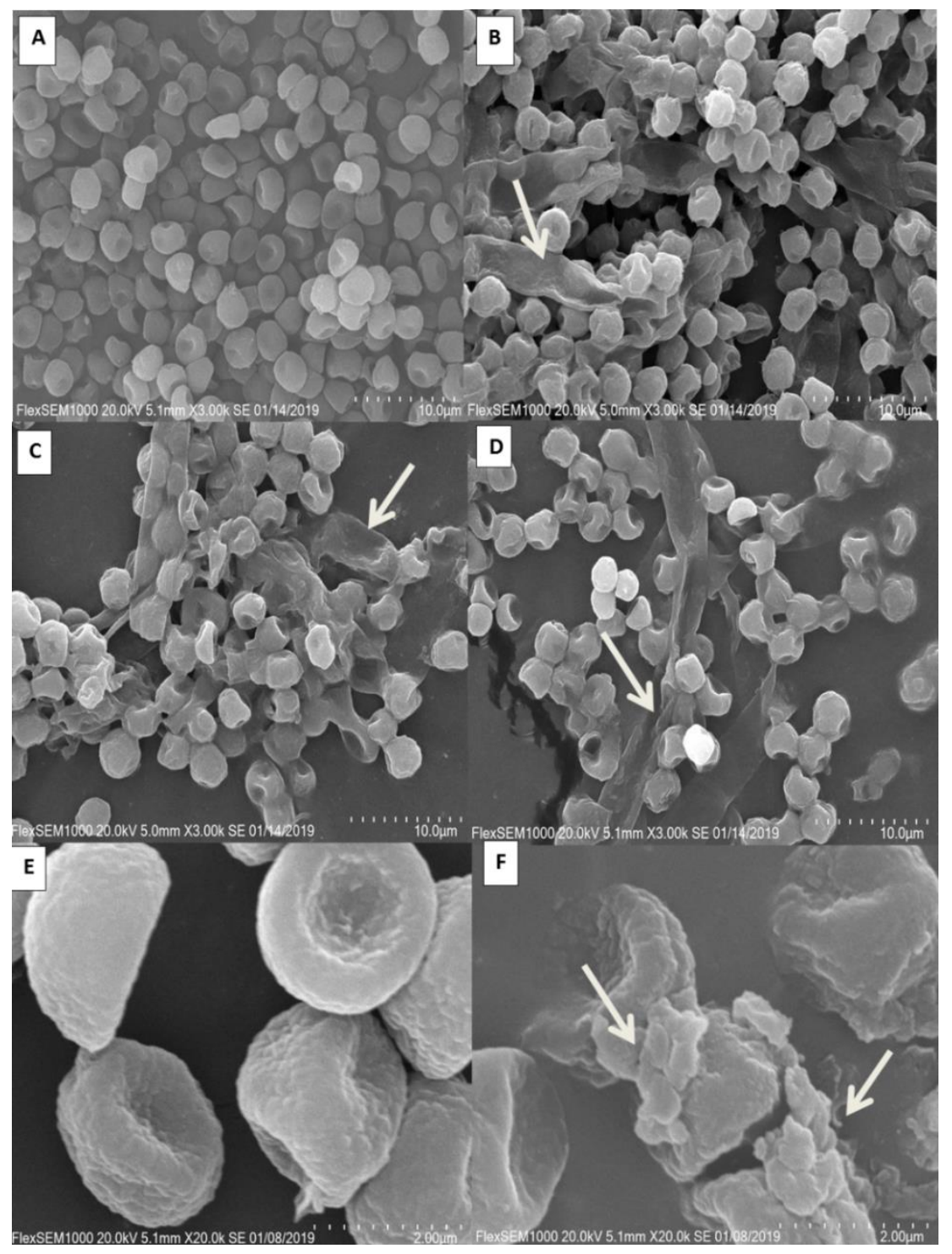

Figure 5. Scanning electron microscopy (SEM) micrographs of strain $\mathrm{Pb}-\mathrm{G}$ treated by different concentrations of $P b^{2+}$. (A and $E, 0 \mathrm{mg} / \mathrm{kg}(C K) ; B, 2000 \mathrm{mg} / \mathrm{kg} ; \mathrm{C}, 3000 \mathrm{mg} / \mathrm{kg} ; D$ and $F, 4000$ $\mathrm{mg} / \mathrm{kg} ; \mathrm{A}, \mathrm{B}, \mathrm{C}$ and $\mathrm{D}$ were amplified by 3000 times, and $E, F$ were amplified by 20000 times)

\section{$X R D$ analysis}

The Penicillium sp. $\mathrm{Pb}-\mathrm{G}$ grown under $0 \mathrm{mg} / \mathrm{L}(\mathrm{CK})$ and $4000 \mathrm{mg} / \mathrm{L} \mathrm{Pb}\left(\mathrm{NO}_{3}\right)_{2}$ treatments were further analyzed by X-ray diffractometry. The XRD patterns of Penicillium sp. $\mathrm{Pb}-\mathrm{G}$ cells treated with 0 and $4000 \mathrm{mg} / \mathrm{L} \mathrm{Pb}\left(\mathrm{NO}_{3}\right)_{2}$ were different 
(Figure 6). Analysis by using Jade 6.0 software and phase retrieval, it was found that the characteristic peaks of $\mathrm{Pb}-\mathrm{G}$ cells under the treatment of $4000 \mathrm{mg} / \mathrm{L} \mathrm{Pb}{ }^{2+}$ (marked by black triangles) contained $\mathrm{Pb}$ elements, in which the characteristic peaks were the highest when the diffraction angle was $30.16^{\circ}-30.30^{\circ}$. But there was no obvious characteristic peak under $\mathrm{CK}$ treatment and no $\mathrm{Pb}$ elements were found by phase retrieval. In this study, $\mathrm{Pb}-\mathrm{G}$ cells treated with $4000 \mathrm{mg} / \mathrm{L} \mathrm{Pb}\left(\mathrm{NO}_{3}\right)_{2}$ contained $\mathrm{Pb}$ with different compound forms, of which the characteristic peak was highest and there was no $\mathrm{Pb}$ element in the fungi of CK group when the diffraction angle was $30.16^{\circ}-30.3^{\circ}$. It can be inferred that the $\mathrm{Pb}$ elements in $\mathrm{Pb}-\mathrm{G}$ mainly come from the exogenous $\mathrm{Pb}\left(\mathrm{NO}_{3}\right)_{2}$ solution, indicating that the strain Penicillium sp. $\mathrm{Pb}-\mathrm{G}$ had biosorption capability to exogenous $\mathrm{Pb}^{2+}$.

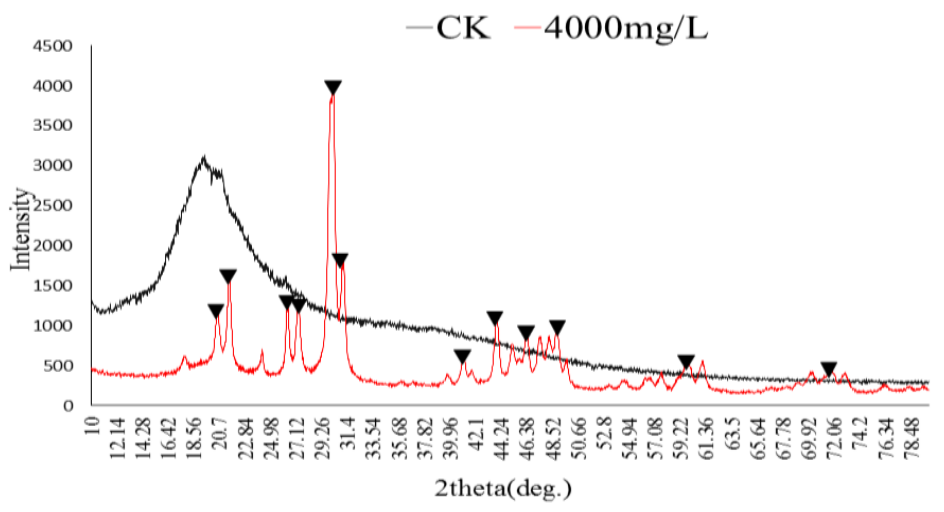

Figure 6. X-ray diffractogram of strain Penicillium sp. $P b-G$ treated by different concentrations of $P b^{2+}$

\section{Analysis of the biosorption of $\mathrm{Pb}^{2+}$ by the strain $\mathrm{Pb}-\mathrm{G}$}

In this study, as the results shown in Table 1, it can be seen that the fungus Penicillium sp. $\mathrm{Pb}-\mathrm{G}$ had good biosorption efficiency at different initial concentration of $\mathrm{Pb}^{2+}$, and the trend of biosorption characteristics of $\mathrm{Pb}^{2+}$ by Penicillium sp. $\mathrm{Pb}-\mathrm{G}$ was also be shown in Figure 7, both the biosorption capacity and biosorption rate were increasing at first and then decreasing with the increasing of $\mathrm{Pb}^{2+}$ concentration. When the $\mathrm{Pb}^{2+}$ concentration was $1500 \mathrm{mg} / \mathrm{L}$, the biosorption influence of strain $\mathrm{Pb}-\mathrm{G}$ was optimal, on which the biosorption rate and biosorption amount was $53.05 \%$ and 178.02 $\mathrm{mg} / \mathrm{g}$, respectively. When the $\mathrm{Pb}^{2+}$ concentration was more than $1500 \mathrm{mg} / \mathrm{L}$, both the biosorption amount and the biosorption rate of Penicillium sp. $\mathrm{Pb}-\mathrm{G}$ showed a rapid decline. Based on these findings, this strain has excellent biosorption capacity for $\mathrm{Pb}^{2+}$.

Table 1. The biosorption efficiency of $\mathrm{Pb}^{2+}$ by Penicillium sp.Pb-G

\begin{tabular}{c|c|c|c}
\hline $\begin{array}{c}\text { The Initial } \\
\text { concentration of } \mathbf{P b}^{\mathbf{2 +}} \\
(\mathbf{m g} / \mathbf{L})\end{array}$ & $\begin{array}{c}\text { The residual } \\
\text { concentration of } \mathbf{P b}^{\mathbf{2 +}} \\
(\mathbf{m g} / \mathbf{L})\end{array}$ & $\begin{array}{c}\text { Biosorptioncapacity } \\
(\mathbf{m g} / \mathbf{g})\end{array}$ & $\begin{array}{c}\text { Biosorptionrate } \\
(\mathbf{\%})\end{array}$ \\
\hline 500 & $426.95 \pm 0.66$ & $28.25 \pm 1.6 \mathrm{e}$ & $14.61 \pm 1.9 \mathrm{e}$ \\
1000 & $729.54 \pm 0.48$ & $125.45 \pm 3.2 \mathrm{~b}$ & $27.05 \pm 1.5 \mathrm{~b}$ \\
1500 & $704.25 \pm 0.16$ & $178.02 \pm 3.9 \mathrm{a}$ & $53.05 \pm 1.0 \mathrm{a}$ \\
2000 & $1509.10 \pm 1.62$ & $88.51 \pm 2.8 \mathrm{c}$ & $24.55 \pm 0.8 \mathrm{c}$ \\
2500 & $2092.70 \pm 0.68$ & $51.26 \pm 0.9 \mathrm{~d}$ & $16.29 \pm 0.9 \mathrm{~d}$ \\
\hline
\end{tabular}

Note: Values are means $\pm \mathrm{SD}, \mathrm{n}=3$. Different letters indicate significant differences among the treatment means $(p<0.05)$ 


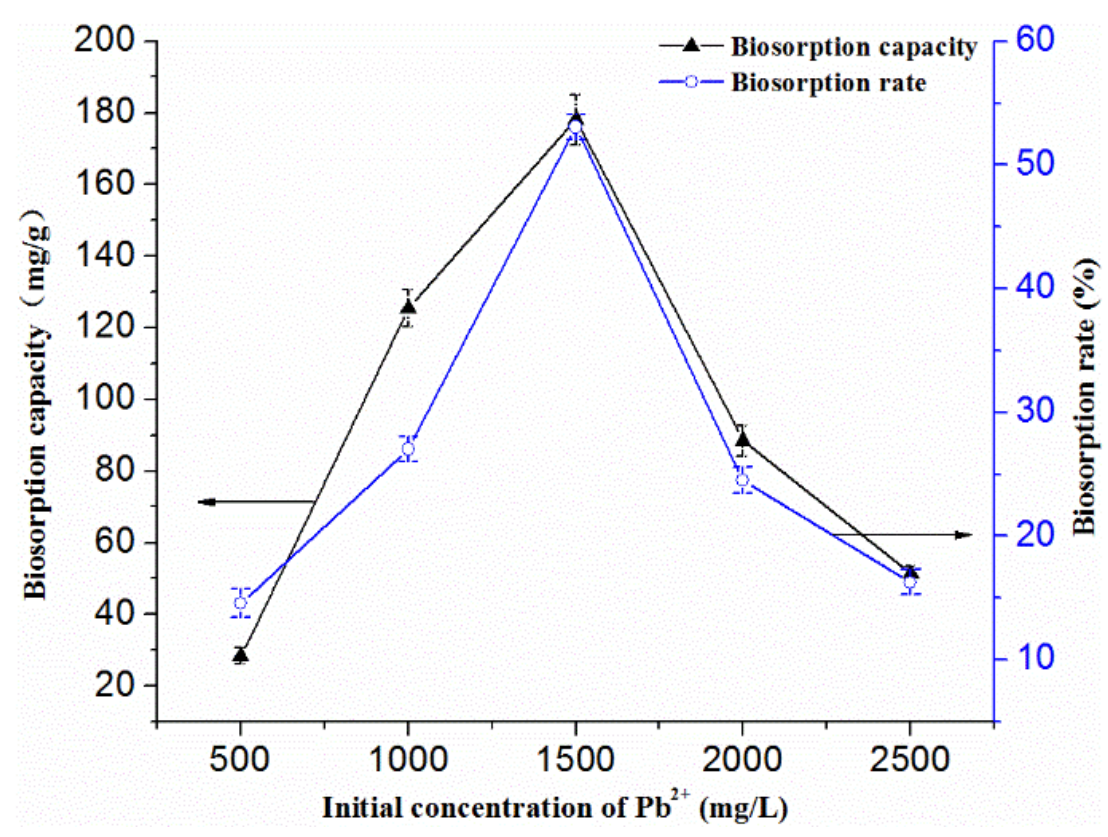

Figure 7. Biosorption characteristics of Penicillium sp. Pb-G treated by different concentration of $\mathrm{Pb}^{2+}$

\section{Discussion}

$\mathrm{Pb}$ is highly toxic to living organisms. In a long-term $\mathrm{Pb}$-contaminated environment, a number of microorganisms have evolved various mechanisms to counteract $\mathrm{Pb}$ stress and thereby improved their tolerance to $\mathrm{Pb}$. Jacob et al. (2013) isolated three strains which were highly-resistant to $\mathrm{Pb}$ and Se from polluted seawater, namely Aspergillus, Fusarium and Penicillium, which can still grow on the medium contained high concentrations of $\mathrm{Pb}$ and Se. Iram et al. (2015) studied two strains of Aspergillus flavus and Aspergillus niger isolated from soil, which were highly resistant to $\mathrm{Pb}^{2+}$ and $\mathrm{Cu}^{2+}$, and the biosorption capacity of A.niger to $\mathrm{Pb}^{2+}$ was $3.25-172.25 \mathrm{mg} / \mathrm{g}$. Velmurugan et al. (2010) reported that Penicillium sp. MRF-1 can grow within the range of $\mathrm{Pb}^{2+}$ concentration from 0.31 to $1.24 \mathrm{~g} / \mathrm{L}$. Heavy metal resistant strains generally exist in areas contaminated by heavy metals, but the resistance levels of the same genus were inconsistent, and their resistance levels always depend on the level of contamination at the site of separation and the extent of heavy metal contamination in the separation test level (Jacob et al., 2013). The resistance of strain $\mathrm{Pb}-\mathrm{G}$ to $\mathrm{Pb}$ in this study was similar to that of the previous studies. However, due to the high level of contamination at the isolation site, the strain $\mathrm{Pb}-\mathrm{G}$ in this study can grow at a higher $\mathrm{Pb}^{2+}$ concentration and had better biosorption capacity after domestication.

It has been reported that bacteria, fungi and algae often act as biosorbent to remove a variety of heavy metal elements from the environment (Wang et al., 2006; Cain et al., 2008; Wu et al., 2010; Li et al., 2010a; Jacob et al., 2013; Iram et al., 2015), in particular, fungus in the genus of Penicillium had a strong biosorption capacity. Due to a large number of extracellular hyphae outside the cell wall of Penicillium, it had the function of adsorbing heavy metals, and some heavy metals can precipitate on the surface of the growing hyphae (Sintuprapa et al., 2000; Sun et al., 2007). The biosorption process is closely related to the concentration of heavy metal ions and the 
biomass produced by the fungi, the biosorbent has more adsorption sites. When the adsorption site of the biosorbent reaches the saturation of the heavy metal, the biosorption amount gradually decreased (Fan et al., 2008; Pan et al., 2010; Yang et al., 2012). Therefore, as the concentration of heavy metal ions increases, the biosorption rate of the cells increases, and as the saturation of the adsorption sites increases, the biosorption capacity decreases gradually (Yang et al., 2012; Fan et al., 2013). In this study, the biosorption rate of $\mathrm{Pb}^{2+}$ by Penicillium sp. $\mathrm{Pb}-\mathrm{G}$ reached the highest value, and the biosorption amount and biosorption rate began to decrease with the increasing of $\mathrm{Pb}^{2+}$ concentration, which indicated that the adsorption site of the added fungi may be close to saturation level in the biosorption test.

In this study, it was observed by SEM that the spores of Penicillium sp. $\mathrm{Pb}-\mathrm{G}$ under high concentration of $\mathrm{Pb}^{2+}$ were deformed, collapsed and dissolved, and formed a "strip" shape in parallel. During fungal growth, the heavy metal resistant fungus can produce organic chelators and acids (Liang et al., 2016), the solubilizing effects of these compounds may be a probable reason for the spores of Penicillium sp. $\mathrm{Pb}-\mathrm{G}$ deformed and dissolved. XRD analysis showed that Penicillium sp. $\mathrm{Pb}-\mathrm{G}$ cells with $\mathrm{Pb}\left(\mathrm{NO}_{3}\right)_{2}$ treatment contained $\mathrm{Pb}$, but none in $\mathrm{CK}$, which indicated that $\mathrm{Pb}$ in Penicillium sp. $\mathrm{Pb}-\mathrm{G}$ cells was derived from exogenously added $\mathrm{Pb}\left(\mathrm{NO}_{3}\right)_{2}$ solution, indicating Penicillium sp.Pb-G had biosorption function to $\mathrm{Pb}^{2+}$. Raheem et al. (2013) reported that the Enterobacter sp. could produce nitrate reductase and denitrify $\mathrm{Pb}\left(\mathrm{NO}_{3}\right)_{2}$ to $\mathrm{PbO}$ when it was treated by $\mathrm{Pb}\left(\mathrm{NO}_{3}\right)_{2}$, and $\mathrm{PbO}$ peak appeared at a diffraction angle of about $30^{\circ}$ analyzed by XRD. Liang et al. (2016) reported that Aspergillus niger and Paecilomyces grew in $\mathrm{Pb}\left(\mathrm{NO}_{3}\right)_{2}$-containing medium can produce phosphatase, phyticacid and glycerol-2-phosphate can be hydrolyzed by phosphatase, releasing inorganic phosphate and oxalic acid, where by $\mathrm{Pb}\left(\mathrm{NO}_{3}\right)_{2}$ in the solution can be precipitated into $\mathrm{Pb}$-oxalate and $\mathrm{Pb}$-chlorite, and the $\mathrm{Pb}$-chloride can be further converted into $\mathrm{Pb}$-oxalate, which is insoluble or weakly soluble. The Penicillium sp. $\mathrm{Pb}-\mathrm{G}$ in this study showed similar characteristics to the reported strains, and the specific biosorption mechanism needs to be further studied.

The mechanism of adsorption of metal ions by fungi mainly included cell surface adsorption or complexation, intracellular enrichment and efflux, among them, enrichment was mainly achieved by transport of cell membranes inside the cells, while the stage of intracellular and extracellular excretion was when heavy metal ions reach a certain concentration, and the fungi prevented more heavy metal ions from entering the cells through efflux (Congeevaram et al., 2007; Sun et al., 2007; Deng et al., 2011). In the range of different concentrations of heavy metals, the living microbial fungus initiated two different mechanisms, one was biosorption by non-living or non-growing biomass, which was a metabolism-independent and passive uptake process, another was bioaccumulation by living and growing cells, which was mainly an intracellular accumulation (Deng et al., 2011). When the concentration of heavy metal reached a certain range that inhibiting microbial growth, the absorbing capacity of the microorganisms showed a downward trend. In this study, the biosorption rate of the strain Penicillium sp. $\mathrm{Pb}-\mathrm{G}$ was measured in a specific concentration of $\mathrm{Pb}^{2+}$ solution. Within a certain concentration range, the biosorption of $\mathrm{Pb}^{2+}$ by the cell adsorption and enrichment achieved. When the concentration of $\mathrm{Pb}^{2+}$ inhibited the activity of fungi, the biosorption rate and the biosorption capacity tended to decrease. 


\section{Conclusions}

After domestication and isolation, a strain of fungus (Penicillium sp. $\mathrm{Pb}-\mathrm{G}$ ) with high resistance to $\mathrm{Pb}$ was obtained, it can grow in a medium with $\mathrm{Pb}^{2+}$ content of $4000 \mathrm{mg} / \mathrm{L}$. According to the morphological feature and molecular analysis, Penicillium sp. $\mathrm{Pb}-\mathrm{G}$ had a close homology with Penicillium, thus the strain $\mathrm{Pb}-\mathrm{G}$ was classified into the genus of Penicillium. The suitable temperature range for the Penicillium sp. Pb-G growth was $20-30^{\circ} \mathrm{C}$, the most suitable $\mathrm{pH}$ was 7 , and it had a biosorption effect on $\mathrm{Pb}^{2+}$. When the $\mathrm{Pb}^{2+}$ concentration at $1500 \mathrm{mg} / \mathrm{L}$, the best biosorption rate of Penicillium sp. $\mathrm{Pb}-\mathrm{G}$ was $53.05 \%$ and the biosorption amount was up to $178.02 \mathrm{mg} / \mathrm{g}$. This study indicated that Penicillium sp. $\mathrm{Pb}-\mathrm{G}$ strain had high tolerance and outstanding biosorption capacity to $\mathrm{Pb}^{2+}$, it could be as a potential candidate to apply in future for metal remediation from wastewater and heavy metal-contaminated soils.

Acknowledgments. This research was supported by the Social Development Project of Science and Technology Department of Shaanxi Province (2020SF-435), Scientific Research Program Funded by Shaanxi Provincial Education Department (No.18JK0354), and Doctoral scientific research foundation of Xi'an Polytechnic University (BS201922).

\section{REFERENCES}

[1] An, F. Q., Diao, Z., Lv, J. L.(2018):Microbial Diversity and Community Structure in Agricultural Soils Suffering from 4-year Pb Contamination. - Can. J. Microbiol. 64(5): 305-316.

[2] Bao, S.D. (2000): Soil and Agricultural Chemistry Analysis. - Agriculture Publication, Beijing, pp. 355-356.

[3] Cain, A., Vannela, R., Woo, L.K. (2008): Cyanobacteria as a biosorbent for mercuric ion. - Bioresour Technol 99(14): 6578-6586.

[4] Chang, J.J., Shi, Y., Si, G. Z., Yang,Q.C., Dong, J., Chen, J.Q. (2020): The bioremediation potentials and mercury(II)-resistant mechanisms of a novel fungus Penicillium spp. DCF11 isolated from contaminated soil. - Journal of Hazardous Materials 396:122638.

[5] Congeevaram, S., Dhanarani, S., Park, J., Dexilin, M., Thamaraiselvi, K. (2007): Biosorption of chromium and nickel by heavy metal resistant fungal and bacterial isolates. - J Hazard Mater146(1-2): 270-277.

[6] Deng, Z. J., Cao, L. X., Huang, H. W., Jiang, X. Y., Wang, W. F., Shi, Y., Zhang, R. D. (2011): Characterization of $\mathrm{Cd}$ - and Pb-resistant fungal endophyte Mucor sp. CBRF59 isolated from rapes (Brassica chinensis) in a metal-contaminated soil. - J Hazard Mater 185(2-3): 717-724.

[7] Fan, T., Liu, Y.G., Feng, B.Y., Zeng, G.M., Yang, C.P., Zhou, M., Zhou, H. Z., Tan, Z. F., Wang, X. (2008): Biosorption of cadmium(II), zinc(II) and lead(II) by Penicillium simplicissimum: Isotherms, kinetics and thermodynamics. - J Hazard Mater160(2-3):655661.

[8] Ganesh, K. S., Sundaramoorthy, P., Nagarajan, M. (2015): Organic Soil Amendments: Potential Source for Heavy Metal Accumulation. - World Scientific News16: 28-39.

[9] Gisbert, C., Ros, R., Haro, A. D., Walker, D. J., Bernal, M. P., Serrano, R., Navarro, A. J. (2003): A plant genetically modified that accumulates $\mathrm{Pb}$ is especially promising for phytoremediation. - Biochemical and biophysical research communications303(2):440445 .

[10] Glukhova, L. B., Frank, Y. A., Danilova, E. V., Avakyan, M. R., Banks, D.,Tuovinen, O. H., Karnachuk, O.V.(2018):Isolation, Characterization, and Metal Response of Novel, Acid-TolerantPenicillium spp. from Extremely Metal-Rich Waters at a Mining Site in 
Transbaikal (Siberia, Russia). - MicrobEcol76(4): 911-924.

[11] Iram, S., Shabbir, R., Zafar, H., Javaid, M. (2015): Biosorption and Bioaccumulation of Copper and Lead by Heavy Metal-Resistant Fungal Isolates. - Arabian Journal for Science \&Engineering40(7):1867-1873.

[12] Jacob, J.M., Bardhan, S., Raj, M.B. (2013): Selenium and lead tolerance in fungi isolated from sea water. - International Journal of Innovative Research in Science Engineering \&Technology2(7): 2975-2981.

[13] Kayalvizhi, K., Kathiresan, K. (2019): Microbes from wastewater treated mangrove soil and their heavy metal accumulation and $\mathrm{Zn}$ solubilization. - Biocatalysis and Agricultural Biotechnology22:101379.

[14] Li, H. F., Lin, Y. B., Guan, W. M., Chang, J. L., Xu, L., Guo, J. K., Wei, G. H.(2010a): Biosorption of $\mathrm{Zn}(\mathrm{II})$ by live and dead cells of Streptomyces ciscaucasicus strain CCNWHX 72-14. - J Hazard Mater179(1-3): 151-159.

[15] Li, Z. G., Luo, Y. M., Teng, Y. (2010b): Soil and environmental microbiology research method. - Science publisher, Beijing. (in Chinese).

[16] Liang, X., Kierans, M., Ceci, A., Hillier, S., Gadd, G. M. (2016): Phosphatase-mediated bioprecipitation of lead by soil fungi. - Environ Microbiol18(1): 219-231.

[17] Long, B.B., Ye, J., Ye, Z., He, J.Y., Luo, Y.T., Zhao, Y.G., Shi, J.Y. (2020): Cr(VI) removal by Penicillium oxalicum SL2: Reduction with acidic metabolites and form transformation in the mycelium. - Chemosphere253: 126731.

[18] Mohammadian, E., Ahari, A.B., Arzanlou, M., Oustan, S., Khazaei, S. H. (2017):Tolerance to heavy metals in filzmentous fungi isolated from contaminated mining soils in the Zanjan Province, Iran. - Chemosphere185:290-296.

[19] Pan, R., Cao, L., Zhang, R. (2010): Biosorption characteristics of heavy metals cadmium, copper, zinc, lead by Penicillium and Fusarium fungi. - Acta Scientiae Circumstantiae30(3):477-484.(in Chinese).

[20] Raheem, A.E., Shanshoury,E., Elsilk, S.E., Ateya, P.(2013):Uptake of some heavy metals by metal resistant Enterobacter sp. isolate from Egypt. - African Journal of Microbiology Research7(23): 2875-2884.

[21] Say, R., Y1lmaz, N., Denizli, A. (2003): Biosorption of Cadmium, Lead, Mercury, and Arsenic Ions by the Fungus Penicillium purpurogenum. - Separation Science \&Technology38(9): 2039-2053.

[22] Sintuprapa, W., Thiravetyan, P., Tanticharoen, M. (2000): A possible mechanism of $\mathrm{Zn}^{2+}$ uptake by living cells of Penicillium sp. - Biotechnology Letters22: 1709-1712.

[23] Sun, F., Shao, Z. (2007): Biosorption and bioaccumulation of lead by Penicillium sp. Psf2 isolated from the deep sea sediment of the Pacific Ocean. - Extremophiles11(6): 853858.

[24] Szczygłowska, M., Piekarska, A., Konieczka, P., Namiesnik, J. (2011): Use of Brassica plants in the phytoremediation and biofumigation processes. - Int. J. Mol. Sci. 12(11): 7760-7771.

[25] Torres-Cruz, T.J., Cedar,H.,Kuske, C. R., Alfaro, A.P. (2018): Presence and distribution of heavy metal tolerant fungi in surface soils of a temperate pine forest. - Applied Soil Ecology131:66-74.

[26] Velmurugan, N., Hwang, G., Sathishkumar, M., Choi, T. K., Lee, K. J., Taek, B.O., Lee, Y. S.(2010): Isolation, identification, $\mathrm{Pb}$ (II) biosorption isotherms and kinetics of a lead adsorbing Penicillium sp. MRF-1 from South Korean mine soil. - Journal of Environmental Sciences22(7): 1049-1056.

[27] Viraraghavan, T., Srinivasan, A. (2011):Fungal Biosorption and Biosorbents. - Springer Science Business Media B.V. Netherlands. Doi:10.1007/978-94-007-0443-5.

[28] Wang, J.L., Chen, C.(2006): Biosorption of heavy metals by Saccharomyces cerevisiae: a review. - Biotechnology Advances 24(5): 427-451.

[29] Wu, G., Kang, H. B., Zhang, X. Y., Shao, H. B., Chu, L. Y., Ruan, C. J.(2010): A critical review on the bio-removal of hazardous heavy metals from contaminated soils: Issues, 
progress, eco-environmental concerns and opportunities. - J Hazard Mater174:1-8.

[30] Yang, L., Hao, R., Feng, W.U. (2012): Isolation of lead-tolerant fungus and the adsorption effect to $\mathrm{Pb}^{2+}$. - Acta Scientiae Circumstantiae 32(10):2366-2374.(in Chinese).

[31] Ye, B. H., Luo, Y. T., He, J. Y., Sun, L. J., Long, B. B., Liu, Q. L., Yuan, X. F., Dai, P. B., Shi, J. Y. (2018):Investigation of lead bioimmobilization and transformation by Penicillium oxalicum SL2. - Bioresource Technology264:206-210.

[32] Zucconi, L., Ripa, C., Alianiello, F., Benedetti, A., Onofri, S. (2003): Lead resistance, sorption and accumulation in a Paecilomyces lilacinus strain. - Biology and Fertility of Soils37(1): 17-22. 